\title{
The ideal model of waqf financing
}

\author{
Ahmad Furqon \\ Faculty of Islamic Economics and Business, UIN Walisongo Semarang, Indonesia
}

\begin{abstract}
Purpose - The aim of this research is to find out the financing mechanism or the waqf assets funding done by nazhir and to find the ideal mechanism for the development of waqf assets.
\end{abstract}

Method - This is a qualitative research with a case study approach. The research object was selected using purposive sampling, namely nazhir waqf in Central Java which manages productive waqf including: Sultan Agung Waqf Foundation (YBWSA), Semarang Grand Mosque Management Agency (BPMAS), and Pekalongan City Muslimin Foundation (YMKP).

Result - This study found that the Sultan Agung Waqf Foundation (YBWSA) implements a mechanism for waqf financing in the form of public funding, government assistance, murabahah, and ijarah. BPMAS implements a waqf financing mechanism in the form of donations \& alms, government assistance, ijarah, and cash waqf. Meanwhile, YMKP provides financing for the development of its waqf assets in the form of government assistance and qardul hasan.

Implication - This study can be used by government, policy maker, business party, or scholar to create an optimal and ideal mechanism in developing waqf assets.

Originality - In the past, studies of waqf asset management were performed in the context of middle east, mostly Kuwait. This study provide waqf asset management in context of South East region.

Keywords: waqf asset management, waqf management in Indonesia 


\section{Introduction}

Waqf is a typical Islamic generosity instrument providing continuous values of virtue for the giver. The benefit of the waqf management is to provide good value for others in need. The result

JIEMB | 40 of waqf can be used for community welfare for social, educational, and economic purposes. The result of waqf can be distributed to the poor, houses of worship, schools, cemeteries, orphanages, the elderly, and so on. Because of its various potential benefits, waqf is a source of strength for Muslims that must be developed properly so that it can bring prosperity.

Nazhir's efforts in developing waqf assets are constrained by several things, including the absence of funds for the development of these waqf assets. The provisions of Islamic Law which prohibit the use of waqf assets to be pawned, used as collateral, and sold, reduce the potential of waqf assets to be used as financing or financing capital. In fact, as this provision is considered to be narrowing the space for nazhirs' movement, it serves the purpose of securing waqf assets in order to maintain their integrity.

According to Masggykuri Abdillah (member of the Institutional Division of the Indonesian Waqf Board), there are three major problems in the development of waqf in Indonesia: first, the perception of waqf is limited to places of worship or tombs, and has not been developed productively so that it has no economic value. Second, the managerial ability of waqf/nazhir managers is still limited. Third, the limited investment funds for productive waqf (Potensi Waqf Indonesia, 2015).

According to Hasanah (2011), when waqif is giving waqf assets to nazhir for management, he does not give additional money to manage them, so nazhir has to think about the cost of maintaining and developing those assets. If nazhir is not creative or does not have sufficient knowledge about the funding or financing to develop the waqf assets, it will result to neglected waqf assets or become undeveloped. This research can serve as a guide for nazhirs in determining the financing or funding mechanism to develop and manage waqf assets.

This research was conducted to find out the ideal financing mechanism according to nazhir productive waqf which does not depend on government assistance but focuses more on the private sector or others. The formulation of the problem in this research is: 
1. What is the financing mechanism that has been carried out by the waqf nazhirs in Central Java?

2. What is the ideal financing mechanism for the development of waqf assets in Central Java?

\section{Literature review}

Studies on the mechanisms for financing waqf assets have been the concern of scholars for a long time. Previously, scholars have discussed financing mechanisms related to efforts to protect waqf assets from damage or extinction (Kahf, 2006).

Al-Kabisi in his book entitled Al-Ahkām al-Waqf fi asy-Syarīah al-Islamiyah mentions two financing models carried out by previous well known scholars: Ibdāl/istibdāl and al-ljārah (Al-Kabisi, 2004: 349). In addition, Kahf (2006) discusses the financing of waqf property in his book entitled al-Waqf al-lslāmy, tathawwuruh, idāratuh, tanmiyyatuh. Kahf classified the waqf financing mechanism, which he called shiyagh tamwīl al-awqāf, into two, namely the traditional financing mechanism and the modern financing mechanism. The traditional financing mechanism according to Kahf is adding the old waqf with the new waqf (atTamwīl bi Idhāfati Waqf Jadīd ilā al-Waqf al-Qadīm), borrowing waqf assets (al-lqtirādh lil waqf), exchanging waqf assets (Istibdāl alWaqf), monopolying waqf property (al-H) ukr fi al-Waqf), and leasing waqf property (al-ljāratāni fi al-Waqf). As for modern financing mechanisms, Kahf divides it into two; first, coming from the internal financing mechanism by empowering waqf assets, the financing model can be in the form of al-Murābah\} ah, al-ljārah and al-Istis\} $n \bar{a}$ ' and second, the external financing model by relying on public or government assistance (Kahf, 2006).

There are several studies discussing the mechanisms for financing waqf assets such as the dissertation research conducted by Bin Azuz (2003) at al-Jazair University with the title Fiqh Istis|mār al-Waqf wa Tamwīluh fi al-Islām (Dirāsat Tat) biqiyah 'an al-Waqf alJazāir). Before discussing the mechanism of financing waqf, the researcher explains the provisions of Islamic financing and its peculiarities. The financing mechanisms mentioned in this study are al-Musyārakah, al-Musāqāt, al-Mughārasah, al-Muzāra'ah, al-Ba'i, as-Salam, al-Mud\} ārabah, al-Murābah\} ah, al-Istishnā' or alMuqāwalah, al-Ji'alah, Stock Company, voluntary financing such as financing from alms, bank loans, and solidarity posts. The object of 
this research is the financing and investment of waqf assets in Algeria.

Another study done on the matter was conducted by Al-Hājary (2006) with the title Taqyīm Kafāat Istismār Amwāl al-Awqāf bi Daulah al-Kuwait. This study describes the measurement of the investment capacity of waqf assets in Kuwait. The research begins by discussing the meaning of investment, types of investment, investment tools applicable in the capital market and Islamic investment tools. The core of the research is to explain the mechanism for the financing of waqf assets and the development of waqf investment in Kuwait.

Another research was conducted by Sabit, Iman, and Omar (2005) at the Malaysia University of Technology Research Center entitled an Ideal Financial Mechanism for Development of the Waqf Properties in Malaysia. This study discusses the ideal financing mechanism for land waqf development in Malaysia. Several financing models are described by classifying them into four classifications, namely: classic financing models, institutional finance-based financing models, financing company-based financing models and finance-based financing models itself. The research concludes that the ideal financing mechanism applied in Malaysia is through cash waqf.

In addition to research reports, there are several studies discussing the mechanism for land waqf financing. Dawwabah (2005) explains the definition of financing, the basic principle of financing, stated that the basic law of all forms of financing is permissible as long as there is no syara' argument against it. The determination of the financing model is a matter of ijtihadiyah, which allows changes and differences based on benefits and needs according to the time and place. There are several principles that must be understood in making financing, namely (1) the conditions proposed by the waqif are the same as those of Allah SWT, which must be followed; (2) current assets waqf is allowed; (3) exchange of waqf assets can be done in a state of emergency; (4) waqf must be managed by nazhir who is in charge of the financing of waqf assets. The author proposes forms of financing, namely: family sukuk, public interest sukuk, investment sukuk, and shanādīq alIstitsmār.

The last study was conducted by Mohammad Thahir Tsabit Haji Mohammad (2009) entitled Alternative Development Financing 
Instruments for Waqf Properties. In this article, several models of land waqf financing are mentioned, such as Join Ventura, Sukuk, Mudhārabah Bonds, ljārah, Money Waqf, Stock Waqf, and Exchange of Land for Cash Waqf.

\section{Methodology}

This research uses an inductive research strategy with qualitative analysis methods. Questions that have been formulated were answered by utilizing the theory of waqf financing.

The stages of the research are as follows:

1. Determining the research object, namely waqf nazhirs of YBWSA, BPMAS, and YMKP.

2. Collecting field data. The data are collected using interview techniques and documentations. Interviews were conducted with nazhirs in the three institutions.

3. Analyzing the data. The analysis of the collected data was carried out using the inductive-descriptive method. Inductive analysis is done by summing up the facts so that the separate facts can be organized into a coherent series. Descriptive analysis is done by fully describing the results of the inductive analysis above through written language that is easy to understand.

\section{Results and discussion}

\section{Endowment financing at the Sultan Agung Waqf Foundation}

Sultan Agung Waqf Foundation (YBWSA) has several assets derived from individual waqf and the proceeds from the purchase of the foundation. The donated land handed over to YBWSA is managed in the form of establishing elementary school (SD) educational institutions, namely SD 1-3 on Jalan Suromenggalan 62, SD 4 on Jalan Kaligawe, and for the development of SD 1-3 in Kauman. Meanwhile, YBWSA's other assets, such as Sultan Agung University, Sultan Agung Islamic Hospital, Student Food Center (Pumanisa), do not come from individual waqf but through purchases by the Foundation (Supadie, interview, 2015).

However, YBWSA assets originating from the purchase are then considered as the foundation's waqf assets, according to Didiek Ahmad Supadie as YBWSA Secretary (interview, 2015) YBWSA considers them as waqf assets that must be safeguarded. The act of 
considering them as waqf assets will make YBWSA be more careful in managing them, because it is a mandate that cannot be misused. Treating YBWSA assets as waqf can provoke the grace of Allah SWT. YBWSA general chairman Hasan Toha Putra said, as quoted by Supadie (2015), that YBWSA's success was not due to the greatness of its management, but solely because of the grace of Allah SWT.

There are several forms of waqf asset financing that have been carried out by YBWSA in developing managed waqf assets. They are as follows:

\section{Public Funders}

Public funding is funding assistance from the community in the form of donations, alms, or benevolent loans. In developing the donated land, YBWSA receives donations and alms from the community, both in an active and passive ways. Active means being active in raising funds from the community. This was done when the Sultan Agung University was about to establish a hospital. Meanwhile, the passive ones were donations and alms that came to YBWSA. The fact is that the passive way begins with the donors' knowledge of the programs that are being carried out by YBWSA and their trust in YBWSA. At the beginning of its establishment in 1950, the Waqf Board received the first donations from philanthropists which were distributed through K. Abdullah worth f.172.93 (read: one hundred seventy-two rupiah, ninety-three cents).

Furthermore, YBWSA received donations and alms from the congregation of recitation held by the Waqf Board. As stated in the history, HM Sulchan once asked Ustadz Abu Bakar Assegaf's willingness to preach and invite recitation congregations to be willing to provide financial assistance for the completion of school buildings. This invitation was responded positively by the recitation congregation, so that the plan to build a school building could be carried out, with the establishment of a 2 (two) floor building in the Suromenggalan Alley in 1954 (Supadie, 2015). The collection of funds from the donations and alms for the congregation has been continuing until now.

The construction of the Sultan Agung Islamic Hospital also received a lot of attention and assistance from the community, not only from the domestic country but also from abroad. Among other things are 4 VIP rooms, each from Sumitomo Shoji Kaisha Ltd Tokyo, 
NV. HMS \& Co, NV. Sapto Argo Puro and the Sukun Kudus Cigarette Factory which was inaugurated on May 20, 1973.

During the construction of two wards for the care of the dhu'afa (poor people), Sultan Agung Islamic Hospital also received a lot of assistance, including:

1. Assistance from Evangelische Zentral Stelle Fur Entwicklungshilfe EV, Bonn, West Germany with the amount of DM 680,000,-

2. Assistance from PT. Mega Jakarta

3. Assistance from the Djarum Kudus Cigarette Factory

4. Car assistance from CV. Toha Putra

5. Assistance from NV. Aktivum Jakarta, a Philips X-ray machine

6. Langsep cigarette factory (Sultan Agung Islamic Hospital, 2011).

7. Government Assistance

YBWSA finances the development of waqf assets through nonbinding government assistance, such as during the construction of Sultan Agung University, the Waqf Board received government assistance. For example, the funds received by YBWSA during the construction of an Elementary School (SD) in Suromenggalan Alley, with the amount of Rp. 50,000,- (fifty thousand rupiah) from Islamic aid funds in Jakarta, through H. A, Ghaffar Ismail as Secretary General of Islamic Aid Funds (Supadie, 2015).

During the construction of the Sultan Agung Hospital, the Waqf Board also received government assistance, such as the assistance from the Government of Indonesia (President Soeharto) in the form of a Toyota Crown Ambulance, cash assistance amounting to Rp. 2,500,000 from the Central Java Provincial Government, an ambulance car assistance from Jasa Raharja Insurance, along with a set of tools for emergency measures, as well as ambulance assistance from the Regional Office of the Ministry of Health, Central Java Province including the medicines (40 Years Book Team of Sultan Agung Islamic Hospital, 2011).

The large number of donors shows the people's trust in YBWSA. In addition, it also shows the ability of YBWSA administrators in establishing cooperation and shilaturrahim with donors. Murabahah financing was mura taken by YBWSA in developing waqf assets. The funds for murabahah were taken by YBWSA to buy equipment for the Sultan Agung Islamic Hospital (Supadie, interview, 2015). YBWSA makes it possible to take 
murabahah financing because the collateral used is not in the form of waqf assets but instead it uses waqf assets obtained by buying.

2. Ijarah

YBWSA also received funds for the development of waqf assets by renting out the kiosks in the Pumanisa building. There are two floors utilized for business ventures; the first floor is leased to stalls selling student lecture needs, such as photocopy centers, internet cafes, stationery stores, etc. Meanwhile, the second floor is rented out for stalls selling snacks for students. In Pujasera (food counters) there are 24 food vendors, 1 cafe, and 10 beverage outlets renting lots to trade in Pumanisa (Pumanisa Unissula, 2015).

\section{Endowment financing at the Semarang Grand Mosque Management} Agency

Waqf financing at the Semarang Grand Mosque Management Agency (BPMAS) provides financing for the development of its waqf assets using several forms of financing mechanisms, namely:

\section{Infaq and alms}

Funding through infaq and alms is carried out by BPMAS to finance the operation of the Great Mosque of Semarang, renovation of the mosque, to pay for the preacher and ustadzs who do the recitation, as well as to finance the celebrations of Islamic holidays held by BPMAS. In one month, the infaq obtained by BPMAS from the mosque infaq box can reach 20 million and double the amount during the fasting month. The donation was also used to buy land in the former Bojong Hotel which is next to the mosque. For the purchase of land from the former Hotel Bojong, $40 \%$ of the gas station, $30 \%$ of the mosque's treasury, and $30 \%$ of the community's donation were taken (Akhmad, interview, 2015).

\section{Ijarah}

BPMAS develops the donated land assets owned by renting the land to investors or people who are interested in working on or who wants to occupy the land. As one of BP's assets, the Great Mosque of Semarang leased a building next to the mosque to BRI bank for a rental fee of Rp. 150 million. Meanwhile, the land for lease is the land of the Great Mosque of Semarang which is located in Demak, precisely in Wonokerto Village, Karang Tengah District, with a lease period of 2 (two) years, from 2012 to 2014. They collected Rp. 41,750,000,- for the result of leasing the land. BPMAS also leased the waqf land in Kendal, in Tanjung Sari Village, Weleri 
District, in 2014. From the renting of paddy fields they received Rp. 20,250,000,- (Banda Masjid Agung Semarang Empowerment Team, 2014).

As of the waqf land occupied by residents, a lease agreement is made by the residents. For the waqf land located in Semarang City, BPMAS created it by making an agreement with the residents of Siwalan Village, to give infaq monthly or daily for occupying the donated land of the Great Mosque of Semarang. In 2014, the funds collected from the donations were Rp. 96,849,600. The amount of funds is only $53.42 \%$ of the initial estimate of incoming funds of Rp. $181,284,638,-$. This is because there are several residents who are in arrears in the payment of these incomes (Bondo MAS Asset Empowerment Team, 2015). BPMAS also rents out productive shops that were previously managed by BKM Kota Semarang.

3. Government assistance

Government assistance was obtained by BPMAS in developing its assets, such as when purchasing a gas station belonging to the former Semarang Mayor Sutrisno Suharto. The gas station was sold for 2 billion, the Central Java Provincial Government provided assistance worth of 1 billion. The provincial government also provided assistance worth of 500 million for the construction of the house of the Imam of the Great Mosque of Semarang (Akhmad, interview, 2015). BPMAS also received government assistance worth of 2 billion for a land distribution project which would have been prepared to build the MAS agro market. However, the project cannot be continued because there is no guarantee from the Ministry of Religion for the continuation of the project (Akhmad, interview, 2015).

\section{Cash waqf}

BPMAS has also rolled out a financing mechanism using the term cash waqf for the purchase of land for the former Hotel Bojong. BPMAS creates coupons with certain stated amounts so that donors can choose accordingly to their capabilities. Through these media, funds are able to be raised from donors. Actually what is done by BPMAS in this case is not included in the money waqf category. However, it is actually a mosque waqf or parking lot waqf, because the purchase of the land is to become the parking area for the Great Mosque of Semarang. While the cash waqf is actually an investment waqf in the banking sector, by depositing, or buying shares, or sukuk. Also, the money is invested in the real productive sector, so 
that the value of the money is not lost but there are still only investment goods, which are worth the money that has been donated.

Endowment financing at the Pekalongan City Muslimin Foundation

Waqf Financing at the Pekalongan City Muslimin Foundation (YMKP) develops its waqf assets by implementing several financing mechanisms, namely:

\section{Government assistance}

YMKP obtains capital to develop its waqf assets, including government assistance, that is from the Directorate General of Islamic Community Guidance (Director General of Islamic Community Guidance) Ministry of Religion of the Republic of Indonesia for the empowerment of productive waqf worth 2 billion in grants. With the help of the Ministry of Religion and loans from several generous people in the city of Pekalongan, YMKP can produce waqf land which was previously an unproductive building, by converting it into productive waqf in the form of an Islamic Business Center, which consists of several business units, namely Sharia hotels, restaurants/culinary business, 1 shophouse and 4 shops.

The total cost needed to fund the Productive Waqf Pilot Project in the form of a Business Center Building is Rp. 3,128,670,500,- with an annual income plan of Rp. 487,940,000,-. In short, the achievement of BEP can be calculated as follows: Rp. 3,128,670,500 : Rp. $487,940,000=6.41$ years $X 360$ days $=2307$ days. Two billion were obtained from the Directorate General of Islamic Community Guidance's Productive Waqf Empowerment Assistance in 2006, while the rest was obtained from loans from individuals.

\section{Individual loans}

In addition to funding from the Directorate General of Islamic Community Guidance's Productive Waqf Empowerment Assistance, YMKP received funds for the empowerment of waqf land owned by individual loans, amounting to Rp. 650,000,000. The loan was obtained without collateral, only because of the trust in YMKP. The person who provided the loan was not a YMKP administrator or involved in managing the waqf at YMKP. However, he made a loan out of trust in YMKP. And YMKP can maintain this trust by repaying the loan in 2010, which only took 4 (four) years from the time of the loan to pay off the loan. 
Ideal waqf financing mechanism according to Nazhir YBWSA, BPMAS, and YMKP

As for what kind of financing mechanism is ideal for waqf nazhir to develop his waqf assets, the three waqf management institutions have their own answers.

According to YBWS, the ideal financing is the easy-to-do financing for nazhir with minimum risk, such as by lease financing and by renting out the waqf land he owns. Since renting out the waqf land does not cost money, it is sufficient for the waqf institution to announce the leased waqf assets (Supadie, interview, 2015). Renting out waqf assets is included in the category of financing that has occurred for a long time. Kahf (2006) determines leasing as a traditional financing mechanism. In the past, this renting method was modified to take the form of hukr, which is a lease with a very long term, so that the tenant can take advantage of the waqf assets that he has rented for a lifetime. Or leasing with two payments (ijaratain). This renting method is also with a long period of time. The first lease payment is a large nominal amount, equal to the value of the waqf assets, while the second lease payment is a small amount that is paid periodically every month or year.

Using this first large payment, nazhir can produce other waqf assets. However, the majority of waqf experts do not agree with the long-term lease model because it can cause the loss of waqf assets due to the length of the leasing period and the absence of profits that can harm the recipient of the waqf. Another problem raising from renting out land is if the land is not located in a strategic location or is infertile to serve agricultural purposes so that nazhir must seek other types of financing besides leasing the land.

YBWSA actually has other financing models that can be done, and it is of added value to YBWSA compared to other waqf nazhirs. It is financing with cash waqf. YBWSA was approved by the Indonesian Waqf Board (BWI) as cash waqf nazhir on April 5, 2011, and YBWSA was listed as the first cash waqf nazhir in Indonesia (Sultan Agung Islamic Hospital's 40 Year Compilation Team, 2011: 53). That way, the money that people send for cash waqf is transferred to the YBWSA account. YBWSA is required to introduce

Journal of Islamic Economics, Management, and Business-Vol 2. No.2 (2020) 
itself to the community as money waqf nazhir by bringing interesting programs having positive and good values for the community.

According to BPMAS, the ideal waqf financing is to borrow funds from donors or investors because it does not require bureaucracy and complicated requirements as if borrowing from a bank (Akhmad, interview, 2015). However, before borrowing nazhir must calculate whether it is possible to return the loan from the profit of the productive business that will be carried out.

Loan-based funding, known as qard hasan fiqh, is a form of funding for productive waqf land. However, qard hasan funding has a risk of loss if the productive waqf financed by the loan suffers a loss while nazhir does not have any collateral to compensate for the losses. Therefore, before applying for a loan, nazhir must make careful calculations about the business prospects to be carried out, so as to minimize the potential for losses.

In Islamic banks, there is financing with qardul hasan. Qardul hasan funds in the bank are obtained from zakat, donations and alms from bank employees, or from fines paid by customers. The bank does not apply a margin or interest for the borrower of the fund. Therefore, nazhir can take the opportunity to apply as a recipient of qardul hasan funds from Islamic banks.

According to YMKP, ideal financing is the same as BPMAS's view, which is through loan funds to members of the community who can afford it. YMKP has experience borrowing funds from a national entrepreneur from Pekalongan, and YMKP was able to repay the loan.

YBWSA and BP can provide many alternative funding. MAS and YMKP can produce the waqf land that is managed, or to procure new waqf, in addition to the forms of funding that have been carried out by the three nazhir institutions, including:

Musyarakah or collaboration between nazhir and investors, in the form of continuous cooperation or cooperation which reduces the ownership of one party and ends with the ownership of the other party.

Musyarakah Mutanaqisah Momitiyah bi al-Tamlik. BPMAS manages the waqf land in collaboration with investors to build a shop or lodging unit. The profits from the business are continuously divided in half. Another way is BPMAS buys shares from the owner of the capital from the profits until they finally own the shop or inn. The funding model is using musyarakah carried out by the Dewam 
of Islam in Pulau Pinang Malaysia with JKP.Sdn. Bhd., a state-owned company in Malaysia as a developer, to build 36 housing units. The profit from the sale of the house is shared between the two parties (Hasan \& Abdullah, 2008).

Funding using the Build, Operate, Transfer (Build, Use, Transfer) system. YBWSA, BPMAS or YMKP as the representative of the waqif submits the construction of the project to the investor to finance the development within a certain period. The investor is given a concession right to manage the building concerning its economic benefits (or a percentage of profit sharing). After the agreed time period has passed, the management of the building is then given to YBWSA, BPMAS or YMKP as the owner of the waqf land.

Muasasah Tanmiyah AMWAI al-AUQA in Jordan applies the BOT model to build a large trade center that is the AI-Istiqlal Mall, which is funded by private investors, worth of 30 million dollars. This mall consists of 200 shops and a parking lot that can accommodate 600 cars according to the agreement with investors. Muasasah will receive an annual rent of 75,000 Dinar and will own it in full after 25 years. In Malaysia, the Pulau Pinang Malaysia Islamic Religious Council followed this method of constructing a 21-story UMNO tower building in George Town. This building was established on waqf land and leased to the developer for 99 years, at the end of the lease period, the Council will own the building by sale transaction. The BOT funding model is also practiced in the construction of the MARA building in Lebuh Buckingham with a lease period of 30 years (Hasan \& Abdullah, 2008).

Funding using istisna' model. YBWSA, BPMAS or YMKP asked Syari'ah Bank to build an establishment with clear specifications. The bank appointed a developer to build the desired building by YBWSA, BPMAS or YMKP. After the building was completed, the developer handed it over to the bank, then the bank handed over the building to YBWSA, BPMAS or YMKP. YBWSA, BPMAS or YMKP then pays the building construction costs in full or in installments until the agreed time period. 


\section{Conclusion}

Based on the results of the research, it can be concluded that: The Sultan Agung Waqf Foundation (YBWSA) has implemented a waqf financing mechanism in the form of public

JIEMB | 52 funding, government assistance, murabahah, and ijarah. BPMAS has implemented a waqf financing mechanism in the form of donations \& alms, government assistance, ijarah, and cash waqf. Meanwhile, YMKP provides financing for the development of its waqf assets in the form of government assistance and qardul hasan.

YBWSA considers that the ideal financing is the one that nazhir can easily do and has minimal risk, that is to lease out the waqf assets they own. Meanwhile, BPMAS and YMKP consider that the ideal financing for the development of waqf assets is qardul hasan (benevolence loan).

\section{References}

Al-Hājary, Abdullah Sa'ad, 2006, Taqyīm Kafāat Istitsmār Amwāl al-Awqāf bi Daulah al-Kuwait, Kuwait: al- Amānah al-'Âmah lil Auqāf.

Al-Kabisi, M.A.A. (2004). Ahkam al-Waqf fi al-Syari'ah al-Islamiyah, Terj, Ahrul Sani Fathurrahman, Hukum Wakaf, Jakarta: IIMaN \& Dompet Du'afa.

Bin Aziz, Abdul Qadir, 2003, Fiqh Istitsmār al-Waqf wa Tamwīluh fi al-Islām (Dirāsat Tathbiqiyah 'an al-Waqf al-Jazāir), PhD Dissertation. AlJazair University.

Dawwabah, A.M. (2005). Tashawwur Muqtarah lil Tamwīl bi al-Waqf. Awqāf. 9th ed.

Hasan, Z., \& Abdullah, M. N. (2008, February). The Investment of Waqf Land as an instrument of Muslims: Economic development in Malaysia. In The Dubai International Conference on Endowments' Investment, February (pp. 4-6).

Hasanah, U. (2011). Cash Waqf and People Economic Empowerment in Indonesia. Ekonomi Dan Keuangan Indonesia, 59(2), 215.

Kahf, Monzer,2006, al-Waqf al-Islamy, Tathwuruh, Idāratuh, Tanmiyyatuh, Suriah: Dār al-Fikr.

Mohammad, M. T. T. H. (2009). Alternative development financing instruments for waqf properties. Malaysian Journal of Real Estate, 4(2), 45-59. 
Sabit, M. T., Iman, A. H. M., \& Omar, I. (2005). An ideal financial mechanism for the development of the waqf properties in Malaysia. Pusat Pengurusan Penyelidikan. Malaysia: Universiti Teknologi Malaysia.

Supadie, D.A. (2015). Wakaf Mensejahterakan Umat Rekam Jejak Yayasan Badan Wakaf, Semarang: Unissula Press.

Tim Buku 40 Tahun RSI Sultan Agung, 2011, 40 Tahun RSI Sultan Agung Mengabdi dan Melayani. 
Ahmad Furqon

JIEMB | 54

Journal of Islamic Economics, Management, and Business-Vol 2. No.2 (2020) 